\title{
The effects of perceived deviancy on interpersonal evaluation*
}

\author{
MARYANNE R. DiMATTEO \\ Tufts University, Medford, Mass. 02155
}

One hundred and twenty high school student Ss read a fictitious transcript from an interview for a study-abroad program. During the interview, a male college student applicant (1) revealed that he had experienced either a happy or an unhappy childhood and (2) presented himself as normal, previously mentally ill, or as having suffered a serious physical illness. Ss evaluated the stimulus person less favorably when he reported either an unhappy childhood or a serious physical illness. The predicted dislike and derogation of the mentally ill stimulus person was not evidenced, but the Ss rated him as the most interesting. Consistent sex differences emerged, as female Ss evaluated the stimulus person in more favorable terms and indicated that, if they were to meet him, they would like him significantly more than did male Ss.

Investigators of the stigma of mental illness have found that a person who has been hospitalized for a mental illness suffers a considerable depreciation of social esteem. Attitudes toward him tend to be very strongly negative (Farina \& Ring, 1965; Lamy, 1966). In a study of conditions expected to mitigate the powerful, negative connotations of mental illness, Farina, Holland, \& Ring (1966) hypothesized that Ss induced to view a stimulus person's past mental illness with a set to understand its occurrence as situationally determined would view that person less negatively than would Ss set to judge that stimulus person's departure from normality as a reflection of his internal dispositions. In the former case, Ss were led to believe that a confederate suffered an unhappy childhood, but in the latter case that he had experienced a rather typical and happy childhood. A condition in which the confederate presented himself as normally adjusted was also crosscut by the set variable. Using as dependent measures the intensity and duration of electric shocks delivered by the $S$ in a teacher-student paradigm, Farina, Holland, and Ring found that the experience of an unhappy childhood tempered the harshness of the treatment accorded the "ex-mental patient" but had an opposite and extremely marked effect for the "normal." The harshest treatment was given to the normally adjusted confederate who presented himself as having experienced a bad childhood, and he was as unfavorably evaluated as

* Sincere thanks fo Professor Walter Swap, Department of Psychology, Tufts University, for help and advice. Thanks also to J. David Nuttall, Principal of Billerica Memorial High School, and to Angeline E. DiMatteo and James Richardson for assistance in obtaining Ss. when he presented himself as mentally ill.

The fact that the confederate was consistently more favorably evaluated in the condition where he presented himself as normally adjusted and as having experienced a typical childhood than he was in the other three conditions suggests that a rather usual person is better liked than one who is "different." Researchers have found that perceived similarity to another results in greater attraction to him than does perceived dissimilarity (Newcomb, 1956; Izard, 1960; Byrne, 1961). Thus, presuming that Ss saw themselves as healthy and as having experienced a reasonably tolerable upbringing, their perceived similarity to the normal confederate who reported a typical childhood could account for their attraction to him and their less favorable evaluation of the confederate who was mentally ill and/or who had experienced a deviant upbringing. This finding is also consistent with the results of the research of Freedman \& Doob (1968), which indicate that deviation from implicit norms, regardless of its direction, is cause for dislike and derogation by nondeviants.

Farina, Holland, and Ring suggested that a bad childhood, or perhaps any deviant experience, is stigmatizing. To the extent that stigmatization can be assumed from harsh treatment and from expressed dislike and derogation, this suggestion seems to be at least partially supported by their results. The mentally ill confederate was consistently less favorably evaluated on the questionnaire measures than was the normal. However, the "stigmatizing" effect of a bad childhood is less clear, for in neither the behavioral nor the rating scale measures did significant effects due to type of childhood (the set variable) emerge. A significant interaction effect on the behavioral measures indicated that, for the normally adjusted stimulus person, the report of a bad childhood led to greater punishment than the report of a good childhood, but this effect was reversed for the mentally ill confederate. On the questionnaire measures, the negative effect of a bad childhood was evidenced only for the normal. Thus, the role of set in Ss' behavior toward and evaluation of stigmatized others was not clearly specified by these results. The present study is designed to take another look at the effects of "differentness" - differentness resulting from a mental illness stigma, from the deviant experience of a serious physical illness, and from an atypical and unhappy childhood. It is expected that a stimulus person who reports an illness and/or a deviant upbringing, perhaps because he is perceived by $\mathrm{Ss}$ as dissimilar to themselves, will elicit unfavorable evaluation and negative affect.

In this study, an attempt was made to determine whether discrepancies existed in the attribution of responsibility to "typical" and "atypical" stimulus persons for a socially undesirable act. Pepitone (1958) has suggested that a strong and direct relationship exists between attractiveness and the causal factors of responsibility and intentionality. The actions of a disliked, unattractive other are seen as having more negative intentions than those of an attractive, well-liked other. Thus, the former should be seen as more to blame for a socially undesirable act. It is expected here that by virtue of his unattractiveness, the "different" stimulus person (one who is ill and/or has experienced a deviant upbringing) will be assigned more blame and responsibility for violent behavior than a seemingly normal and "usual" stimulus person.

A brief remark should be made regarding the measures employed in this study. A serious case against the use of rating scales in person perception research has been made by Jones \& Sigall (1971), who have suggested that in stigma studies, Ss are very likely to suppress negative affect toward stigmatized others when using paper-and-pencil rating scales. However, the effects of a mental illness stigma were clearly evidenced in the rating scale measures of the Farina et al study. Although no attempt is made here to defend the use of rating scales, it seems, on the basis of the Farina et al findings, that rating scale measures are adequate for the purposes of this investigation. SUBJECTS

The Ss were 60 male and 60 female suburban Boston high school students 
Table 1

Mean Ratings of Stimulus Person on Six Dimensions and Responses on Questionnaire Items*

\begin{tabular}{|c|c|c|c|c|c|c|c|c|c|c|c|c|}
\hline \multirow{3}{*}{$\begin{array}{l}\text { Adjustment } \\
\text { Childhood } \\
\text { Sex of S }\end{array}$} & \multicolumn{4}{|c|}{ Normal } & \multicolumn{4}{|c|}{ Mentally Ill } & \multicolumn{4}{|c|}{ Physically Ill } \\
\hline & \multicolumn{2}{|c|}{ Good } & \multicolumn{2}{|c|}{ Bad } & \multicolumn{2}{|c|}{ Good } & \multicolumn{2}{|c|}{ Bad } & \multicolumn{2}{|c|}{ Good } & \multicolumn{2}{|c|}{ Bad } \\
\hline & $\mathbf{M}$ & $F$ & M & $F$ & $\mathbf{M}$ & $\mathrm{F}$ & M & $F$ & $\mathbf{M}$ & $\mathbf{F}$ & $\mathrm{M}$ & $F$ \\
\hline Evaluative (4-32) & 23.8 & 26.9 & 22.5 & 25.0 & 25.2 & 27.0 & 22.3 & 26.5 & 25.4 & 25.7 & 25.3 & 24.5 \\
\hline Predictability (3-24) & 15.7 & 18.6 & 13.9 & 14.2 & 14.8 & 15.2 & 14.1 & 16.1 & 15.2 & 19.2 & 17.2 & 14.8 \\
\hline Intelligence (2-16) & 12.1 & 13.1 & 12.7 & 12.5 & 11.3 & 13.2 & 10.4 & 12.5 & 12.9 & 12.0 & 11.5 & 12.5 \\
\hline Character (Evaluative) (4-32) & 24.4 & 27.6 & 25.6 & 27.1 & 26.4 & 28.6 & 24.3 & 28.2 & 25.2 & 26.8 & 27.1 & 26.4 \\
\hline Tense-R elaxed $(1-8)$ & 5.1 & 6.2 & 4.6 & 4.7 & 5.5 & 5.2 & 4.3 & 5.2 & 5.4 & 6.2 & 3.5 & 5.2 \\
\hline Boring-Interesting (1-8) & 4.6 & 4.3 & 4.2 & 6.6 & 5.1 & 5.7 & 5.4 & 6.6 & 4.9 & 5.6 & 4.5 & 4.3 \\
\hline Truthfulness (1-8) & 5.9 & 6.4 & 6.4 & 7.0 & 7.0 & 7.1 & 5.9 & 7.2 & 5.5 & 6.2 & 6.4 & 5.4 \\
\hline Liking of John (1-8) & 5.5 & 5.9 & 4.9 & 6.6 & 6.1 & 6.4 & 5.8 & 6.6 & 5.1 & 6.0 & 5.7 & 6.0 \\
\hline Intentionality (1-8) & 4.5 & 3.1 & 4.8 & 4.2 & 4.6 & 3.4 & 4.1 & 4.1 & 4.2 & 4.5 & 5.1 & 4.1 \\
\hline Blame $(1-8)$ & 4.7 & 4.6 & 4.7 & 4.4 & 5.0 & 4.7 & 4.4 & 5.4 & 5.2 & 5.4 & 5.7 & 5.2 \\
\hline Relative Punishment $(1-8)$ & 4.9 & 4.1 & 4.2 & 4.4 & 4.3 & 4.0 & 4.0 & 4.3 & 4.6 & 4.6 & 4.3 & 4.8 \\
\hline
\end{tabular}

Note-Numbers in parentheses refer to the possible range of scores on the measure. A higher score indicates a more favorable rating of John and more perceived truthfulness, greater liking and greater intentionality, blame and relative punishment.

*Each mean in the table is based on cell $N=10$.

selected from junior and senior classes in biology, chemistry, and physics. These classes were, for the most part, designed for college preparation.

\section{MATERIALS}

Each $S$ was given a booklet of mimeographed pages which contained all necessary instructions. The first page informed him that he was taking part in a study of impression formation, and he was instructed to read the transcript of a tape-recorded interview (fictitious) for a study-abroad program. During the interview, the stimulus person (a college student named John) revealed that he had either a normal and happy childhood (good childhood condition) or an unhappy and pathogenic childhood (bad childhood condition). For a third of the Ss in each of these groups, John then revealed that he was normally adjusted (normal condition), had been hospitalized for a mental illness (mentally ill condition), or had been hospitalized for rheumatic fever (physically ill condition). Each hospitalization was for a period of 6 months. A specific attempt was made to equate the scripts across the six conditions, except for the words constituting the experimental manipulations. The remainder of the booklet was the same for all Ss regardless of condition.

The next page contained 23 8-point scales of the semantic differential type and six questions regarding the S's attitude toward John. These questions were followed by a brief report of a "follow-up" of John's progress in the study-abroad study, which revealed that John was dismissed from the program and was on academic probation at the University because he and another student engaged in a violent knife fight. "John suffered cuts and bruises and the other student was hospitalized," the S read, "but the cause of the fight is still being investigated and responsibility for the violence has not yet been determined." This was followed by six questions (each on an 8-point scale) pertaining to the S's opinion about the intentionality of John's actions, his degree of blame, the amount of control he had over his actions, and the degree to which he should be punished.

During each of five $50-\mathrm{min}$ experimental sessions (conducted in the space of 1 day), 24 Ss were assigned randomly to six experimental conditions. An equal number of male and female Ss were assigned to each condition. On the basis of this random assignment, the mimeographed booklets (coded by condition) were distributed. Throughout the instructions, it was emphasized to the Ss that they should answer according to their own personal impression of John.

\section{RESULTS}

Four indices were constructed by combining related semantic differential scales, and a S's score on each index was obtained by summing his ratings of John on the scales related to that index. The four indices and their related scales are: evaluative (bad-good; unpleasant-pleasant; unfamiliar-familiar; strange-not strange), predictability (changeable-stable; does not plan ahead-plans ahead; unpredictablepredictable), intelligence ( unintelligent-intelligent; unsuccessful-successful), and cha-acter (evaluative) (cruel-kind; violent-gentle; dishonest-honest; untruthful-truthful). Separate analyses of variance were performed on each of these indices, on two individual scales (interesting-boring and relaxed-tense), and on the questions pertaining to the $S$ 's attitude toward John and his assignment of responsibility for the violent incident. The means of these measures appear in Table 1.

The Ss in the good childhood condition rated John more favorably on the evaluative index $(\mathrm{F}=4.62, \mathrm{df}=$ $1 / 108, p<.05)$ and on the predictability index $(\mathrm{F}=4.33, \mathrm{df}=$ $1 / 108, p<.05)$ and felt that he was more relaxed $(F=7.46, \mathrm{df}=1 / 108$, $\mathrm{p}<.05$ ) than did $\mathrm{Ss}$ in the bad childhood condition.

Significant main effects of adjustment revealed that $S s$ in the physically ill condition felt John was least truthful during his interview ( $F=$ $4.49, \mathrm{df}=2 / 108, \mathrm{p}<.05$ ) and most to blame for the fight $(\mathrm{F}=3.46, \mathrm{df}=$ $2 / 108, p<.05)$ and that $S s$ in the mentally ill condition rated John as the most interesting $(\mathrm{F}=3.39$, df $=$ $2 / 108, \mathrm{p}<.05)$.

Consistent main effects of sex of $\mathrm{S}$ emerged as female Ss rated John more favorably on the evaluative $(F=9.12$, $\mathrm{df}=1 / 108, \mathrm{p}<.01)$, intelligence $(\mathrm{F}=$ $5.83, \mathrm{df}=1 / 108, \quad \mathrm{p}<.05)$, and character (evaluative) $(\mathrm{F}=11.63, \mathrm{df}=$ $1 / 108, p<.01$ ) indices than did male Ss. In addition, female Ss rated John as significantly more interesting $(\mathrm{F}=$ 5.96 , df $=1 / 108, p<.05)$, liked him better $(\mathrm{F}=10.43, \mathrm{df}=1 / 108$, $\mathrm{p}<.01$ ), and attributed less intentionality to his hurting the other student in the fight $(\mathrm{F}=4.19, \mathrm{df}=$ $1 / 108, p<.05)$.

A significant Childhood by Sex of $\mathbf{S}$ interaction $(F=4.81, \mathrm{df}=1 / 108$, $\mathrm{p}<.05)$ reflected the fact that male Ss in the good childhood condition felt that John should be punished more in relation to the other student in the fight than did male $\mathrm{Ss}$ in the bad childhood condition.

\section{DISCUSSION}

The results of this study lend only partial support to the notion that "differentness," in a number of forms, elicits dislike and derogation. In the Farina et al (1966) study, as in the 
bulk of the previous research on the stigma of mental illness, Ss evaluated an ex-mental patient significantly less favorably than they did a normally adjusted person. Interestingly enough, this finding was not replicated in the present study, although on some indices the stimulus person who reported having suffered a serious physical illness was nore negatively evaluated than the others. While in the Farina et al siudy no significant main effects due to type of chillahood were evidenced, in this suady a devaluation of the stimulus person who had suffered a bad childhood occurred on a number of measures.

The analyses of variance revealed almost no differencesin the attribution of responsibility for a socially undesirable act. It is possible that the knife fight was perceived by the Ss in this sample, not as a socially undesirable act, but as a relatively neutral one. If this is the case, no differential attributions of responsibility could have been expected. However, if the action were, in fact, seen as socially undesirable, it seems that the perception of dissimilarity, contrary to expectation, did not result in the assignment of more (or less) responsibility or intentionality for the fight. Only on the question of blame did Ss make this distinction. The physically ill stimulus person was judged to be the most to blame for the fight.

Perhaps the most consistent finding of this study is the difference between male and female Ss in their perception of the male stimulus person. Female Ss rated John more positively on three of the four indices, rated him as more interesting, and attributed less intentionality to his violent act than did male Ss. When asked how they thought they would feel about John if they were to meet him, female Ss indicated that they would like him significantly more than did male Ss.

One might speculate as to why the dislike and derogation of the mentally ill stimulus person, clearly evidenced in a number of previous studies, did not appear here. It may have been that Ss were reluctant to express negative affect for someone with a stigma, seeing this as a response which was not expected of them. Thus, they may have "played it safe" and suppressed what may have been their true feelings. However, the fact that this suppression was confined to the mentally ill condition makes this explanation tenuous. Ss readily expressed derogation of the stimulus person who suffered a serious physical illness and/or a deviant upbringing. In view of the extensive literature on the relationship between similarity and attraction, another explanation suggests itself. It may have been that Ss' attraction to the mentally ill stimulus person was due to their perceived similarity to him. While this explanation is logically sound, it seems improbable that a majority of the Ss in the mentally ill condition saw themselves as emotionally disturbed and therefore similar to the mentally ill stimulus person.

A more plausible explanation for failure to replicate the results of previous studies may be found in the fact that Ss were drawn from a population of high school students, while much of the previous research on the stigma of mental illness was done with college students (Farina et al, 1966; Lamy, 1966) or with older Ss (Gergen \& Jones, 1963). To these high school Ss, who have perhaps had less exposure to current myths of mental illness, the stigmatizing effect of a mental breakdown may simply not be salient. Mental illness may not be seen as illness at all, but rather as a slightly glamorous state. This may indeed be the case, as the analysis of variance indicated that the mentally ill stimulus person was rated the most interesting of the three conditions of adjustment. If this latter explanation proves, in future research, to be correct (i.e., that the stigma of mental hospitalization is indeed not salient to individuals of high school age), it seems that they are the persons toward whom education regarding the realities of mental illness should be directed. While their seemingly glamorous image of the ex-mental patient would be revlaced by a more realistic view, powaps their exposure to the fear, hold by the wider society, of the "vysticism" and "strangeness" of the ex.mental patient and the stigma of mental illness itself may remain nonsalient.

\section{REFERENCES}

BYRNE, D. Interpersonal attraction and attitude similarity. Journal of Abnormal \& Social Psychology, 1961, 62, 713-715.

FARINA, A., HOLLAND, C. H., \& RING, $K$. The role of stigma and set in interpersonal interaction. Journal of Abnormal Psychology, 1966, 71, 421-428.

FAR INA, A., \& RING, K. The influence of perceived mental illness on interpersonal relations. Journal of Abnormal Psychology, 1965, 70, 47-51.

FREEDMAN, J. L., \& DOOB, A. N. Deviancy: The psychology of being different. New York: Academic Press, 1968 .

GERGEN, K. J. \& JONES, E. E. Mental illness, predictability, and affective consequences as stimulus factors in person perception. Journal of Abnormal \& Social Psychology, 1963, 67, 95-104.

IZARD C. E. Personality similarity, positive affect, and interpersonal attraction. Journal of Abnormal \& Social Psychology, 1960, 61, 484-485.

JONES, E. E., \& SIGALL, H. The bogus pipeline: A new paradigm for measuring affect and attitude. Psychological Bulletin, 1971, 76, 349-364.

LAMY, R. E. Social consequences of mental illness. Journal of Consulting Psychology, $1966,30,450-455$.

NEWCOMB, T. M. The prediction of interpersonal attraction. American Psychologist, 1956, 11, 575-586.

PEPITONE, A. Attributions of causality, social attitudes, and cognitive matching processes. In $R$. Tagiuri and $L$. Petrullo (Eds.), Person perception and interpersonal behavior. Stanford: Stanford University Press, 1958. Pp. 258-276. 